Article

\title{
ESG Issues among Fund Managers-Factors and Motives
}

\author{
Justyna Przychodzen 1,*, Fernando Gómez-Bezares ${ }^{2}$, Wojciech Przychodzen ${ }^{2}$ \\ and Mikel Larreina ${ }^{2}$ \\ 1 Laureate Online Education, University of Liverpool Online Management Programmes, \\ 1101 BH Amsterdam, The Netherlands \\ 2 Deusto Business School, University of Deusto, Avda de las Universidades 24, 48007 Bilbao, Spain; \\ f.gomez-bezares@deusto.es (F.G.-B.); wojciech.przychodzen@deusto.es or \\ wojciech.przychodzen@yahoo.com (W.P.); mikel.larreina@deusto.es (M.L.) \\ * Correspondence: justyna.przychodzen@online.liverpool.ac.uk; Tel.: +34-944-361-321 \\ Academic Editor: Yongrok Choi
}

Received: 24 May 2016; Accepted: 18 October 2016; Published: 24 October 2016

\begin{abstract}
This paper investigates the motives, behavior, and characteristics shaping mutual fund managers' willingness to incorporate Environmental, Social and Governance (ESG) issues into investment decision making. Using survey evidence from fund managers from five different countries, we demonstrate that this predisposition is the stronger, the shorter their average forecasting horizon and the higher their level of reliance on business risk in portfolio management is. We also find that the propensity to incorporate ESG factors is positively related to an increasing level of risk aversion, an increasing importance of salary change and senior management approval/disapproval as motivating factors as well as length of professional experience in current fund and increasing significance of assessment by superiors in remuneration. Overall, our evidence suggests that ESG diligence among fund managers serves mainly as a method for mitigating risk and is typically motivated by herding; it is much less important as a tool for additional value creation. The prevalent use of ESG criteria in mitigating risk is in contrast with traditional approach, but it is in line with behavioral finance theory. Additionally, our results also show a strong difference in the length of the forecasting horizon between continental European and Anglo-Saxon fund managers.
\end{abstract}

Keywords: fund managers; institutional investors; ESG investing; investment behavior; behavioral finance; asset management; survey

\section{Introduction}

Environmental, Social and Governance (ESG) investments have seen growing significance in the academic, business and political domains. The origin of the ESG notion is grounded in the field of Socially Responsible Investment (SRI), which are investment strategies that embrace not only economic aspects but also environmental, social, and governance issues [1]. Thus, the ESG concept is also called the three pillars of sustainability [2] and has many labels, such as Ethical, Green, Impact, Mission, Responsible, Socially Responsible, Sustainable and Values, which embrace strategies (including environmental, social and corporate governance criteria) to generate long-term competitive financial returns and positive societal impact [3].

In the past several years, the SRI market has been continually expanding around the world. The total amount of US-domiciled assets under management using strategies that actively incorporate social, environmental, and governmental issues in the investment decisions increased from $\$ 3.74$ trillion at the beginning of 2012 to $\$ 6.57$ trillion at the beginning of 2014 (an increase of 76 percent in two years). In Europe, they comprise approximately $41 \%$ ( $€ 7$ trillion) of total professionally managed assets [1]. 
The SRI market is also growing rapidly in Canada, where assets engaged in sustainable investing strategies increased from $\$ 589$ billion to $\$ 945$ billion from 2012 to 2014 [4].

Stakeholders around the world are raising concerns about ESG issues and expect financial markets to address and reflect these concerns. A recent survey by the Forum for Sustainable and Responsible Investment revealed that 80 percent of fund managers who address ESG issues did so as the result of client pressure [3]. Ignoring ESG issues in investment activities may result in obstruction, social disgrace, and losing license to operate [5]. Thus, the motivation of fund managers for ESG investing, as well as their attitudes and general working environment characteristics are of substantial importance.

The main aim of this study is to analyze the motives, behavior and characteristics of ESG-sensitive fund managers. Particularly, we want to identify the key drivers of ESG investment among fund managers and answer the following questions: Is the predisposition to incorporate ESG issues in investment decision making influenced more by "objective" (e.g., professional experience, type of fund managed, and major investment segment) or "subjective" (e.g., personal points of view, attitudes, and perceptions) manager characteristics? Is the strength of the above tendency motivated more by risk aversion, herding (following of other fund managers' actions) or a desire to create additional value?

This study is of potential importance for academics, the asset management industry and financial professionals. It contributes to the discussion on the motivations and behavior of fund managers toward ESG investments by offering empirical evidence on additional important factors, which are not covered in the existing body of literature, such as: experience in the current fund, working hours, major investment segment, type of fund managed, assets under management, forecasting horizon, tendency to herd, loss aversion, performance-based remuneration characteristics or work motivators. It also sheds light on the true reasons for ESG investment strategy implementation in the asset management industry, which are more related to risk aversion and herding behavior, than to the sole creation of additional value.

This paper is organized as follows: First, the review of the previous studies on ESG investment motives among fund managers is provided. Second, three potential drivers of fund managers' behavior (risk avoidance, herding behavior and shareholder value creation) in the ESG area are presented. Third, the research method and the data used are described. Next, an empirical model is presented and the obtained results are analyzed. Finally, key findings are discussed and recommendations are offered.

\section{ESG and Fund Managers-Review of the Literature}

Investing with respect to ESG issues requires an analysis of several non-financial dimensions of a company's performance, such as the firm's impact on the natural environment (e.g., carbon emissions, water and energy use), society (e.g., product safety, health and safety, philanthropy, and fair trade principles), and the quality of corporate governance (e.g., corruption and bribery, board independence, and stakeholders activity and protection). All of these dimensions, which have become key indicators of management competence, risk management, and non-financial performance, are thoroughly scrutinized by the ESG portfolio manager in order to construct a diversified portfolio [6-8].

The topic of ESG, its characteristics and importance for firms and their performance is widely covered in the literature [9-12]. Similarly, the concept of ESG investing is of interest to many researchers [13-19]. However, the motives, expectations, behavior and characteristics of fund managers investing in ESG stocks are much less often explored in the literature. Among existing studies in that area, Hong and Kostovetsky [20] discussed the role of fund managers' political values in their investing in ESG stocks. With the use of the KLD score as a measure of firm responsibility, the authors found, that managers, who are more Democrat-leaning are more willing to invest in firms with positive social features, such as excellent employee relations and clean environmental records. McLachlan and Gardner [21] analyzed differences between socially responsible and conventional investors. On the basis of the analysis of dedicated questionnaires collected from 109 individual investors (54 respondents classified as socially responsible, and 55 as conventional), the authors reported no significant relationship between investor type and age, education level, income, "ethical" 
profile (self- vs. other-centered), importance of return on investment, and decision-making style. The findings of MacLachlan and Gardner [21] are in contrast with the study of Bauer and Smeets [22], who found that social sensitivity and identification are stronger among highly educated, younger and low-wealth investors.

MacLachlan and Gardner [21] further report that socially responsible investors rated ethical issues as being more important and were characterized by higher expectations toward quality and higher general levels of moral intensity. The different motivations of ESG investors were also emphasized by Nilsson [23], who noticed that investor motivation for responsible investing depends on his/her attitude towards financial and ESG elements of the service. On the basis of questionnaire's results sent to financial professionals that owned at least one SRI profiled mutual fund, the author found that there is a group of investors perceiving financial return as more important than social responsibility and making responsible investment solely due to financial reasons. Furthermore, Nilsson [23] concludes that there also exist other group of investors who do not put financial return as the primary objective of investment. This second group, according to the author, "considers socially responsible factors to be more important than financial return for the SRI portion of their investments, (but) not for their overall portfolio of funds ([23], p. 26)". Glac [24] used 121 surveys collected from undergraduate students to analyze some of the possible factors influencing the likelihood of engagement in socially responsible investing. The author found that individuals who tend to express their values in portfolio selection and have high expectations for corporate social responsibility are more likely to invest in shares of responsible firms. This attitude is significantly higher in periods when returns on the conventional investment options are high. Finally, Van Duuren et al. [25] surveyed 126 portfolio managers with respect to their ESG integration practices. The authors found that the majority of investors who take ESG issues into account in their investment decisions do so continually at least for one year and buy shares due to ESG-related information. They also found that these investors have strong expectations about the lower risk and positive impact of ESG investment on performance. The survey revealed that ESG investment practices do not have a huge impact on portfolio diversity, as less than $20 \%$ of the respondents use ESG criteria to limit the investment universe. Van Duuren et al. [25] also analyzed the differences between environmental, social and governance sensitive portfolio managers with regard to their domiciles. They found that European managers have stronger beliefs in the positive influence of ESG factors on performance than do their US colleagues, although the latter have more such expectations with regard to long-term performance and risk reduction. The authors also found that regardless of the country of origin, fund managers place more value in governance rather than social and environmental factors.

In contrast with our work, existing studies did not analyze any additional financial professionals' characteristics, such as experience in the current fund, working hours, major investment segment, type of fund managed, assets under management, forecasting horizon, tendency to herd, loss aversion, performance-based remuneration characteristics or work motivators. Furthermore, they did not offer an empirical model to investigate the relative strength of those factors as drivers of ESG investment among fund managers. In the attempt to fill the above research gap, the framework of this research is built around three broad issues - protection against risk, herding behavior and value creation — which together constitute an important part of the motives, expectations, behavior and characteristics of fund managers active in the area of ESG practices. The new insight into these issues is the main contribution of this study.

\subsection{ESG and Protection against the Risk}

It is a widely accepted concept that the disclosure of ESG data results in a lower volatility of share returns, which in turn significantly reduces the investment portfolio risk [26]. The idea of lower risk of ESG stocks is derived from the principles of the Efficient Market Hypothesis, formulated by Fama $[27,28]$, from which we can deduce that public information about non-financial data increases the accuracy of the company's risk and value assessment. As a result, there is a common practice among investors to conduct an analysis of non-financial ESG data as additional risk factors, which shape the 
company's market value [29] or influence the adoption of risk-based strategies [30]. These strategies aim at specific asset allocation with regard to the risk budgeting allocation approach. They also define the weights of the assets in portfolios as functions of the individual and portfolio risks [31]. Bertrand and Lapointe [30], in their analysis of European stocks, found that a selection of stocks from the SRI universe (which contains only companies with good environmental, social and governance performance) has a positive contribution to the risk-adjusted performance of risk-based allocations.

Depending on the individual attitude toward risk, the ESG issues may have greater or lesser importance in the investment decision making process. Here it is worth mentioning, that there is evidence that risk aversion depends on the domain. Weber et al. [32] presented a psychometric scale of five content domains (financial, health/safety, recreational, ethical, and social decisions) for which the attitude toward risk has been assessed. The authors found, that in case of financial decisions the high level of perceived risks significantly reduced the likelihood of the risk behavior while expected benefits increase the risk behavior only slightly. In the psychological literature, it has been widely evidenced that the propensity toward risky behavior increases during adolescence, peaks in late adolescence/early adulthood, and then declines [33-35]. Thus, risk attitudes change depending on age. This finding is in line with the studies that indicate that individuals' sensitiveness to the natural environment is changing with age, as they engage with nature, seek to avoid environmental harm, and are more interested in conserving natural resources [36,37].

Numerous studies have been conducted to determine the relationship between gender and risk attitudes in investment strategies. In general, there is a consensus among researchers that women are less inclined towards risk taking than men $[38,39]$ and that men behave less carefully and undertake more risky strategies than women in their fund's investment decisions [40,41]. Research conducted by Olsen and Cox [42] among professional investors also revealed that women are more interested in steady returns from investments while men are strongly focused on increasing profits. These findings are also in line with other studies that reveal that women are more sensitive to social cues [41] and place greater value on environmentally friendly practices [43].

Although the majority of funds are managed by a single fund manager, in reality, investment decisions are made after discussions with other professionals within formal or informal social structures. Empirical evidence shows that groups tend to make decisions that are significantly different from the decisions made by individuals. The majority of research reveals that a group is more risk-averse [44] as well as more consistent and moderate in decision making [45,46]. Rockenbach et al. [47] suggest that a group accumulates significantly more expected value at a significantly lower total risk in comparison to individuals. The active engagement of stakeholders in the investments decision making process is in line with the stakeholder theory. Thus, apart from group risk aversion, the expectations of various stakeholders may further strengthen an investment orientation toward ESG stocks. If clients, investors, superiors, or colleagues press fund managers on ESG issues, the fund managers are prompted to ensure that selected investment strategies focus more on issues related to certain environmental, social and governance actions. In other words, when a fund manager senses social and public pressure, he/she is more keen to undertake a variety of activities to ease such pressure. In so doing, the fund manager mitigates the risk of obstruction and accusation of misconduct [48].

An analysis of ESG issues may be undertaken both within long- and short-term contexts. The first situation derives from the desire to improve an understanding of the role of future trends in changing business environments like, for example, the progressing climate change, which can strongly influence asset prices [49]. The second situation relates to the threat of significant losses in stock value, which may appear as the result of unexpected company-driven social and/or ecological disasters (i.e., BP lost $55 \%$ of shareholder value after the Deepwater Horizon incident, which caused the largest offshore oil spill in U.S. history). Thus, ESG issues are of potential importance not only over a relatively long-term period but also increasingly for short-term business performance valuation and investment decision making. 


\subsection{ESG and Herding Behavior}

Herding behavior among investors occurs when the majority of them sells or buys the same or similar stocks at the same time, meaning that they adopt identical or similar investment strategies [50]. There are several identified causes of herding behavior among investors. Fund managers may decide not to perform the internal processing of actual information, and imitate others' investment strategies to maintain their reputation [51,52], achieve similar performance [53] or gain access to unattainable external information [54].

Many studies also reveal that herding behavior among investors is more probable among professionals from the same community $[55,56]$, investors who previously positively outperformed others [57] and investors who are less educated in the financial area and do not have significant experience [58]. It has also been evidenced that when the performance of fund managers is assessed relative to others, the fund managers who lack confidence in their skills are afraid of underperforming and thus are more keen to copy the trades of their peers, who are perceived as being more qualified and experienced [51]. Furthermore, market actors who possess more experience or enjoy higher peer status are more likely to be the first finance professionals to adjust their investment assessments based on ESG issues [59].

In other cases, when fund managers are quite homogeneous, herding behavior may also occur accidentally [60]. The factors that may trigger herding behavior are often objective-for example, educational background, investment experience, access to similar information or the common regulatory framework and environment within which they work [61]. Herding behavior may also derive from managers' similar investing styles [62].

Engaging in prosocial behaviors-in our case, ESG investment practices-can establish a reputation of being more trustworthy among peers [63-65]. Thus, the chances of acquiring more friends, allies, romantic partners [66] and higher status in a group [67] are increased. In that sense, the engagement in ESG investment practices can be seen as a way to achieve increase in personal utility [68].

\subsection{ESG and Shareholder Value Creation}

Numerous researchers analyzed the relationship between ESG and shareholder value creation. In general, there is no consensus in the existing body of literature regarding the influence of the incorporation of ESG factors into an investment strategy on the achieved rates of returns. It is worth mentioning that Margolis and Walsh [69], in their 2003 article, counted 109 studies that treated corporate social performance (CSP) as the independent variable and corporate financial performance (CFP) as the dependent variable. Out of these 109 studies, 54 find a positive relationship between CSP and CFP, while only seven find a negative relationship. Apart from this, 28 studies find non-significance and 20 have mixed results. More recent research still struggles to unambiguously prove the character of the ESG and shareholder value creation relationship — for example Derwall et al. [18] found that profit-generating opportunities of ESG stocks exist in the short term but not in the long term.

Some studies state that investors should not expect any abnormal returns from investment in ESG stocks $[15,19,70]$, while other report the positive influence of ESG screening on financial performance. This positive impact on corporate financial results derives from the maximization of shareholder value [71], reputation-related benefits [72,73] cost and risk reduction [74,75], and lower stock price volatility [76]. Cordeiro and Tewari [77] argue that the investor reaction on announcing firm's engagement in ESG activities is the re-estimation of the firm's future cash flows due to the possible retention and attraction of superior employees, the attraction of customers with green preferences, or reducing possible penalties, fines, and other sanctions from regulatory bodies. Thus, we should expect that these effects will be stronger in the long term $[29,78]$.

The assessment of the future company value is often performed through technical or fundamental analysis. Both methods aim at selecting the stocks that enable prospect shareholders to achieve capital gains through an increase in their market value over time. Thus, both are focused on the assessment of 
possible shareholder value creation potential and investment return maximization, which makes them useful tools for fund managers in general as well as for those who are ESG-sensitive.

\section{Research Methods}

The study is based on a questionnaire that was conducted among bank-affiliated mutual fund managers from the US, Canada, Great Britain, Spain and Poland. The choice of the countries of origin was not random as the first three are mature Anglo-Saxon markets, while the last two are middle-developed Continental European markets. The former are characterized by different fund investment patterns than the latter, such as time horizon or stakeholder participation [79]. The choice of Spain was dictated by the high importance of banking sector in its economy, while the choice of Poland by the considerable size of its stock market and importance among the new member states of the European Union (which joined in 2004). In addition, the selection of the above countries was also dictated by the access to mutual fund managers willing to participate in the survey. Furthermore, the adopted selection of countries provided a necessary multicultural diversity of views, perceptions and behavioral patterns.

The choice of target funds was motivated by the substantial importance of bank-affiliated mutual funds in the capital market. Furthermore, their managers are usually more homogenous and professional. The construction of the final questionnaire was preceded by initial consultations with professional asset managers and heads of investment teams as well as a revision of existing studies, some of which have been cited in the previous sections. The above steps aimed at controlling the questionnaire in terms of its clarity and logic. The final questionnaire contains 24 questions (see Appendix A).

To minimize the potential risk of strategic answering [80], all participants remained anonymous. The size and high level of diversification of the final data sample ensure proper representativeness and reliability. Finally, a limited amount of subjectivity was desired to shed additional light on the true motives, behaviors and characteristics of fund managers investing in ESG stocks.

\section{Data Description}

The questionnaire survey conducted among American, Canadian, British, Spanish and Polish bank-affiliated fund managers was used to obtain data for this analysis. The answers were collected from October 2014 to September 2015. From a total of 138 collected questionnaires, 113 were selected as high quality questionnaires that did not contain any contradictory answers (i.e., professional experience in current fund longer than professional experience in general, assets under personal management higher than company total assets under management). The rate of response was $21 \%$.

Table 1 presents the summary statistics of the collected data. The median respondent was approximately 37 years old and his/her professional experience in the asset management industry was approximately 10 years. The value of assets under his/her personal management was almost 210 million EUR, and the annual bonus that he/she received in relation to the fixed salary was about $27 \%$. Women constituted around $41 \%$ of the respondents.

The survey collected the necessary data to identify the key drivers of ESG-investing propensities among fund managers and ascertain whether they are more objective or subjective in nature. The most important question in the questionnaire, which served as a starting point to assess the importance and overall awareness of ESG issues among fund managers, was Q1: "When you make an investment decision, ESG issues are of: no importance, low importance, moderate importance, average importance, considerable importance, extreme importance." Overall, $40.71 \%$ of the respondents claimed that ESG issues are of considerable or extreme importance in their investment decision making, with the highest manager predisposition to incorporate ESG issues into portfolio management among US fund managers $(65 \%)$ and the lowest among their Spanish counterparts $(14.8 \%)$. 
Table 1. Characteristics of respondents.

\begin{tabular}{|c|c|c|c|c|c|c|}
\hline & ALL & US & CAN & UK & ES & PL \\
\hline $\begin{array}{l}\text { Managers with substantial predisposition to incorporate ESG issues into } \\
\text { investment decision making (in \%) (Q1)* }\end{array}$ & 40.7 & 65.0 & 38.1 & 45.0 & 14.8 & 45.5 \\
\hline Median age (in years) & 36.9 & 36.0 & 35.8 & 32.3 & 41.3 & 37.6 \\
\hline Women (in \%) & 40.7 & 39.1 & 42.9 & 55.0 & 40.7 & 27.3 \\
\hline Median professional experience (in years) & 9.6 & 10.4 & 7.1 & 7.0 & 14.3 & 6.8 \\
\hline Median asset management company size (thousands of millions of EUR) & 12.6 & 15.8 & 12.0 & 10.5 & 21.6 & 3.6 \\
\hline Median assets under personal management (millions of EUR) & 209.1 & 406.3 & 175.0 & 118.8 & 437.5 & 62.5 \\
\hline Managers with forecasting horizon longer than 12 months (in \%) & 15.0 & 4.3 & 0.0 & 5.0 & 37.0 & 22.7 \\
\hline $\begin{array}{l}\text { Managers with strong focus on views of fund's senior management } \\
(\text { in \%) (Q14g)* }\end{array}$ & 44.2 & 69.6 & 47.6 & 45.0 & 11.1 & 54.5 \\
\hline $\begin{array}{l}\text { Managers with strong focus on views of fund's participants/clients } \\
\text { (in \%) (Q14h)* }\end{array}$ & 38.9 & 65.2 & 47.6 & 55.0 & 3.7 & 31.8 \\
\hline $\begin{array}{l}\text { Managers with strong focus on behavior of other market players in } \\
\text { investment (in \%) (Q14i)* }\end{array}$ & 47.8 & 69.6 & 42.9 & 50.0 & 22.2 & 59.1 \\
\hline Managers with high risk aversion (in \%) (Q15) ** & 24.8 & 26.1 & 38.1 & 25.0 & 22.2 & 13.6 \\
\hline $\begin{array}{l}\text { Managers strongly motivated by approval/disapproval of fund's senior } \\
\text { management (in \%) (Q20d) }\end{array}$ & 46.0 & 56.5 & 52.4 & 55.0 & 7.4 & 68.2 \\
\hline $\begin{array}{l}\text { Managers strongly motivated by approval/disapproval of fund's } \\
\text { participants/clients (in \%) (Q20e) }\end{array}$ & 65.5 & 78.3 & 38.1 & 55.0 & 70.4 & 81.8 \\
\hline
\end{tabular}

* Defined as percent of managers that answered a given question either considerably or extremely; ${ }^{* *}$ Defined as percent of managers who identified themselves in the Q15 as either considerably or extremely risk averse; *** Defined as percent of managers who stated in a given question, that it is of considerable importance or extreme importance.

Interestingly, only $15 \%$ of all respondents admitted to having forecasting horizon longer than 12 months (with quite substantial differences between the countries-37\% and 22.7\% in Spain and Poland, while only $4.3 \%$ and 5\%, respectively, in the US and UK and none in Canada). The difference in mean forecasting horizons between fund managers from continental European (eight months) and Anglo-Saxon (27 days) countries was statistically significant $(t=8.02, p=0.01)$. The above finding for financial professionals surveyed in our study is in line with general short-term orientation characteristic for neoliberal, Anglo-Saxon investment approach [79]. It can be seen as an additional corollary of our research.

Technical analysis had the lowest level of importance among the surveyed Spanish fund managers, while it was a quite relevant tool for their American and Polish counterparts. The importance of fundamental analysis in investment decision making was generally much higher, without such extreme differences among countries, as in the case of technical analysis. American and Canadian fund managers relied most heavily on discussions with colleagues, while none of Spanish managers attached significant importance to this practice. Spanish managers were also the least prone to adopt the views of senior management and participants/clients or the behavior of other market players while making portfolio management decisions.

Canadian fund managers were the most risk averse among all respondents, as more than $38 \%$ of them admitted being considerably or extremely risk averse. Polish asset managers were the least risk averse, with only 13.6\% stating this. In general, approval of the fund participants was far more important among the surveyed fund managers as a motivator to achieve superior investment performance/avoid poor performance than the approval of senior management $(65.5 \%$ of the respondents assigned considerable or extreme importance to the former versus $46 \%$ to the latter). 


\section{Determinants of Predisposition to Incorporate ESG Issues into Investment Decision Making among Fund Managers}

There are several different factors shaping the possible influence of ESG aspects in portfolio management among asset managers (see ESG and fund managers-review of the literature section). Tables 2-4 provide a rank correlation analysis between the individual levels of the predisposition to incorporate ESG issues into investment decision making and different fund managers' characteristics that were included in our survey.

Table 2. Spearman rank correlations between the level of predisposition to incorporate ESG issues into investment decision making (Q1) and selected fund managers' characteristics.

\begin{tabular}{|c|c|c|c|c|c|c|c|}
\hline $\begin{array}{l}\text { Question } \\
\text { No }\end{array}$ & Variables & ALL & US & CAN & UK & ES & PL \\
\hline Q2 & Gender & 0.037 & -0.021 & 0.351 & 0.091 & -0.268 & -0.074 \\
\hline Q3 & Age & $-0.177^{*}$ & 0.018 & 0.123 & -0.171 & -0.024 & -0.263 \\
\hline Q4 & Educational level & $0.162 *$ & $0.544^{* * *}$ & $0.506^{* *}$ & 0.052 & $0.352 *$ & -0.027 \\
\hline Q5 & $\begin{array}{l}\text { Professional experience in asset } \\
\text { management in general (in years) }\end{array}$ & -0.073 & 0.236 & 0.130 & -0.152 & 0.078 & -0.153 \\
\hline Q6 & $\begin{array}{l}\text { Professional experience in current fund } \\
\text { (in years) }\end{array}$ & $0.218^{* *}$ & $0.482 * *$ & 0.251 & -0.157 & $0.405^{* *}$ & -0.173 \\
\hline Q7 & Average working hours per week & -0.085 & -0.208 & -0.184 & 0.141 & 0.156 & -0.370 * \\
\hline Q8 & $\begin{array}{l}\text { Average number of hours per week for data } \\
\text { procurement and research }{ }^{1}\end{array}$ & 0.137 & 0.128 & $0.435^{* *}$ & 0.045 & 0.017 & 0.026 \\
\hline Q9 & Type of fund managed ${ }^{2}$ & $-0.195^{* *}$ & 0.047 & $-0.462 * *$ & 0.168 & 0.094 & -0.179 \\
\hline Q10 & Major investment segment ${ }^{3}$ & 0.163 * & $0.445^{* *}$ & -0.206 & 0.184 & 0.316 & -0.134 \\
\hline Q11 & $\begin{array}{l}\text { Company's total assets under management } \\
\text { (thousands of millions of EUR) }\end{array}$ & -0.106 & $0.405^{*}$ & 0.054 & -0.236 & 0.255 & -0.249 \\
\hline Q12 & $\begin{array}{c}\text { Assets under personal management } \\
\text { (millions of EUR) }\end{array}$ & 0.060 & $0.553^{* * *}$ & 0.158 & 0.077 & $0.465^{* *}$ & -0.234 \\
\hline Q13 & $\begin{array}{l}\text { Length of forecasting horizon in investment } \\
\text { decision making }\end{array}$ & $-0.355^{* * *}$ & -0.291 & 0.002 & -0.007 & 0.158 & -0.373 * \\
\hline
\end{tabular}

${ }^{1}$ Q8 modified on the basis of Gehrig et al. [81]; ${ }^{2}$ In order to get scale variables we combined answers pension fund, life insurance fund, private client fund and other into single category of "other" (1-mutual fund, 2 -other); ${ }^{3}$ In order to get scale variables we combined answers derivatives and other funds into single category of "derivatives/other funds" (1-derivatives/other funds, 2-equities, 3-Bonds, 4-money market); * Significance at $10 \%$ level; ${ }^{* *}$ Significance at $5 \%$ level; ${ }^{* * *}$ Significance at $1 \%$ level.

Table 2 demonstrates that the following characteristics are connected significantly with the propensity to implement ESG screening into portfolio management by fund managers: age (Q3), educational level (Q4), professional experience in the current fund (Q6), type of fund managed (Q9) and major investment segment (Q10). The predisposition to incorporate ESG issues into investment decision making is also strongly connected with the length of the forecasting horizon in investment decision making (Q13). The correlation analysis presented in Table 2 also reveals that factors such as gender (Q2), professional experience in asset management in general (Q5), average working hours per week (Q7), average number of hours per week for data procurement and research (Q8), company's total assets under management (Q11) and assets under personal management (Q12) are not significantly related to the level of propensity to incorporate ESG issues into portfolio management among fund managers.

Table 3 shows, that the following characteristics are connected significantly with the propensity to implement ESG screening into portfolio management by fund managers: levels of reliance on technical analysis $(\mathrm{Q} 14 \mathrm{~b})$, Beta as a measure of risk $(\mathrm{Q} 14 \mathrm{c})$, volatility of the return $(\mathrm{Q} 14 \mathrm{~d})$, business risk $(\mathrm{Q} 14 \mathrm{e})$, discussions with colleagues (Q14f), views of the fund's senior management (Q14g), views of the fund's participants/client $(\mathrm{Q} 14 \mathrm{~h})$, behavior of other market players $(\mathrm{Q} 14 \mathrm{i})$, statements of industry leaders (Q14j), statements of economic leaders (Q14k), government leaders (Q14l), level of risk aversion (Q15), level of loss aversion (Q16), length of information processing (Q17) and endurance horizon (Q18) in investment decision making. The importance of fundamental analysis in the investment decision making process (Q14a) is not significantly related to the level of propensity to incorporate ESG issues into portfolio management among fund managers. 
Table 3. Spearman rank correlations between the level of predisposition to incorporate ESG issues into investment decision making (Q1) and selected fund managers' characteristics.

\begin{tabular}{|c|c|c|c|c|c|c|c|}
\hline $\begin{array}{l}\text { Question } \\
\text { No }\end{array}$ & Variables & ALL & US & CAN & UK & ES & PL \\
\hline Q14 & $\begin{array}{l}\text { Characteristics of Investment decision } \\
\text { making process: }\end{array}$ & & & & & & \\
\hline Q14a & - Importance of fundamental analysis & 0.146 & 0.166 & $0.553^{* * *}$ & 0.297 & -0.092 & 0.129 \\
\hline Q14b & - Importance of technical analysis & $0.384 * * *$ & $0.362 *$ & $0.546^{* *}$ & -0.014 & 0.080 & 0.070 \\
\hline Q14c & - Importance of Beta as a measure of risk & $0.460^{* * *}$ & $0.481^{* * *}$ & $0.697^{* * *}$ & 0.280 & $0.373^{*}$ & 0.046 \\
\hline Q14e & - Importance of business risk & $0.560^{* * *}$ & $0.528 * * *$ & $0.906^{* * *}$ & $0.530 * *$ & $0.458^{* *}$ & 0.229 \\
\hline Q14f & - Importance of discussions with colleagues & $0.382 * * *$ & $0.572 * * *$ & $0.573^{* * *}$ & $0.567^{* * *}$ & $-0.339 *$ & -0.030 \\
\hline Q14g & $\begin{array}{l}\text { - Importance of views of fund's } \\
\text { senior management }\end{array}$ & $0.431^{* * *}$ & $0.540 * * *$ & $0.770 * * *$ & 0.336 & -0.100 & 0.084 \\
\hline Q14j & $\begin{array}{l}\text { - Importance of statements of } \\
\text { industry leaders }\end{array}$ & $0.425^{* * *}$ & $0.594^{* * *}$ & $0.719^{* * *}$ & $0.440 *$ & 0.065 & -0.052 \\
\hline Q14k & $\begin{array}{l}\text { - Importance of statements of } \\
\text { economic leaders }\end{array}$ & $0.362 * * *$ & $0.543^{* * *}$ & $0.765^{* * *}$ & 0.255 & -0.232 & -0.131 \\
\hline Q141 & $\begin{array}{l}\text { - Importance of statements of } \\
\text { government leaders }\end{array}$ & $0.397 * * *$ & $0.644^{* * *}$ & $0.897^{* * *}$ & 0.137 & -0.043 & -0.064 \\
\hline Q15 & Level of risk aversion & $0.323 * * *$ & 0.276 & $0.733^{* * *}$ & $0.447^{* *}$ & 0.250 & -0.051 \\
\hline Q16 & Level of loss aversion $^{1}$ & $0.432 * * *$ & $0.641^{* * *}$ & $0.641^{* * *}$ & 0.027 & 0.257 & 0.138 \\
\hline Q17 & Length of information processing horizon ${ }^{2}$ & $0.011 *$ & $0.440 * *$ & 0.204 & -0.025 & -0.181 & 0.112 \\
\hline
\end{tabular}

${ }^{1}$ Q16 adopted directly from Lütje [82]; ${ }^{2}$ Q17 and Q18 adopted directly from Menkhoff [83]; ${ }^{*}$ Significance at $10 \%$ level; ${ }^{* *}$ Significance at $5 \%$ level; *** Significance at $1 \%$ level.

Table 4. Spearman rank correlations between the level of predisposition to incorporate ESG issues into investment decision making (Q1) and selected fund managers' characteristics.

\begin{tabular}{clcccccc}
\hline $\begin{array}{c}\text { Question } \\
\text { No }\end{array}$ & \multicolumn{1}{c}{ Variables } & ALL & US & CAN & UK & ES & PL \\
\hline Q19 & $\begin{array}{l}\text { Characteristics of performance } \\
\text { based remuneration: }\end{array}$ & & & & & & \\
\hline Q19a & - Importance of absolute fund performance & $0.364^{* * *}$ & $0.616^{* * *}$ & $0.579^{* * *}$ & 0.006 & $0.528^{* * *}$ & -0.018 \\
\hline Q19b & - Importance of relative fund performance & $0.183^{*}$ & $0.577^{* * *}$ & $0.463^{* *}$ & 0.034 & -0.227 & 0.203 \\
\hline Q19c & - Importance of assessment by superiors & $0.189^{* *}$ & $0.488^{* *}$ & 0.188 & 0.306 & -0.051 & -0.350 \\
\hline Q19d & - Importance of assessment by colleagues & $0.367^{* * *}$ & $0.832^{* * *}$ & $0.505^{* *}$ & 0.368 & $-0.337^{*}$ & $-0.392^{*}$ \\
\hline Q19e & $\begin{array}{l}\text { - Importance of business development of the } \\
\text { asset management company }\end{array}$ & $0.322^{* * *}$ & $0.760^{* * *}$ & $0.646^{* * *}$ & 0.279 & -0.168 & -0.210 \\
\hline Q20 & $\begin{array}{l}\text { Motivators to achieve superior investment } \\
\text { performance/avoid bad performance }{ }^{*}:\end{array}$ & & & & & & \\
\hline Q20a & - Importance of salary change & $0.488^{* * *}$ & $0.520^{* *}$ & $0.566^{* * *}$ & 0.227 & $0.413^{* *}$ & $0.477^{* *}$ \\
\hline Q20b & $\begin{array}{l}\text { - Importance of position change } \\
\text { (promotion/demotion) }\end{array}$ & $0.442^{* * *}$ & $0.495^{* *}$ & $0.710^{* * *}$ & 0.088 & 0.314 & $0.362^{*}$ \\
\hline Q20c & - Importance of possible job loss & $0.404^{* * *}$ & 0.297 & $0.538^{* *}$ & -0.098 & $0.372^{*}$ & 0.270 \\
\hline Q20d & $\begin{array}{l}\text { - Importance of senior management } \\
\text { approval/disapproval }\end{array}$ & $0.479^{* * *}$ & $0.616^{* * *}$ & $0.440^{* *}$ & $0.515^{* *}$ & 0.306 & 0.243 \\
\hline Q20e & $\begin{array}{l}\text { - Importance of client's } \\
\text { approval/disapproval }\end{array}$ & $0.292^{* * *}$ & $0.486^{* *}$ & $0.596^{* * *}$ & 0.128 & -0.256 & $0.377^{*}$ \\
\hline Q20f & - Importance of personal reputation & $0.196^{* * *}$ & $0.429^{* *}$ & 0.259 & $0.413^{*}$ & $-0.514^{* * *}$ & 0.118 \\
\hline
\end{tabular}

${ }^{1}$ Q20 modified on the basis of Baker [84]; * Significance at $10 \%$ level; ** Significance at $5 \%$ level; ${ }^{* * *}$ Significance at $1 \%$ level. 
As presented in Table 4, the propensity to implement ESG screening is also strongly associated with the level of importance of absolute (Q19a) and relative (Q19b) fund performance, assessment by superiors (Q19c) and colleagues (Q19d), as well as business development of the asset management company $(\mathrm{Q} 19 \mathrm{e})$ as determinants of the variable part of remuneration. The importance of a salary change (Q20a), position change (Q20b), threat of job loss (Q20c), senior management (Q20d) and clients' approval/disapproval (Q20e), as well as personal reputation $(\mathrm{Q} 20 \mathrm{f})$ as motivating factors also play a significant role.

Before constructing a formal, multivariate regression model, we eliminated the threat of multicollinearity between some of the statistically significant independent regressors by removing those that were characterized by pairwise correlation coefficients higher than 0.6 from further consideration. This reduced the number of possible characteristics to 19 (see Table 5), which were divided into two categories: "subjective" and "objective." The first group includes factors such as personal interests, points of view, motives and perceptions. The second group comprised factors such as age, professional work experience, education, features of the compensation model and characteristics of the institutional working environment. To control for possible country-specific effects, we also incorporated country dummies in all of the presented models.

Model (1) contains only "subjective" factors (see the first column of Table 5). Results show that the managers of asset management companies were the more predisposed to incorporate environmental, social and governance factors into their investment decision making process, the shorter their average forecasting horizon was. This result, together with the significantly positive influence of the level of reliance on business risk, shows that fund managers are increasingly seeing ESG problems as a source of possible threat for value creation over the short term. The propensity to incorporate ESG factors is also positively related to increasing levels of risk aversion and sensitivity to eventual losses. This, in turn, shows that fund managers perceive proper diligence in the analysis of environmental, social and governance issues as additional protection against risk and possible losses. Model (1) also demonstrates that an increasing level of reliance on Beta and the behavior of other market players as well as the increasing importance of client's approval/disapproval and personal reputation as a motivator is not a sign of higher importance ascribed to ESG issues among financial professionals. Although not statistically significant, the increasing importance of salary change and senior management approval/disapproval were noteworthy predictors.

Model (2) contains only "objective" factors (see the second column of Table 5). This model's explanatory power is much lower than that of Model (1), which could suggest that a general predisposition to incorporate environmental, social and governance factors into the investment decision making process among asset managers is much more a behavioral phenomenon. Nevertheless, the obtained results strongly confirm that the tendency to incorporate ESG factors into the investment decision making process decreases with the manager's age. It demonstrates that younger financial professionals are especially prone to be concerned with ESG issues. Model (2) also indicates that the above predisposition is positively related to longer professional experience in the current fund. It reveals that a more careful approach to ESG factors in portfolio management may be seen as an outcome of higher identification with a given workplace. A stronger predisposition to incorporate environmental, social and governance issues into the investment decision making process is also more characteristic for asset managers that operate in less risky investment segments (money market or bonds rather than equities), whose variable part of the remuneration is more dependent on relative fund performance (thus, more prone to herd-like behavior). On the other hand, the predisposition to incorporate ESG issues into the investment decision making process is not significantly related to educational level, the type of fund managed or the importance of an assessment by superiors in remuneration. 
Table 5. Predisposition to incorporate ESG issues in investment decision making and different fund manager's characteristics-results of ordered regressions.

\begin{tabular}{|c|c|c|c|c|c|c|c|c|c|}
\hline & \multicolumn{3}{|c|}{ Model (1)—Only “Subjective” Factors } & \multicolumn{3}{|c|}{ Model (2)—Only “Objective” Factors } & \multicolumn{3}{|c|}{$\begin{array}{l}\text { Model (3)_“"Subjective" and } \\
\text { "Objective" Factors }\end{array}$} \\
\hline & Coefficient & $\begin{array}{c}\text { Standard } \\
\text { Error }\end{array}$ & $p$-Value & Coefficient & $\begin{array}{c}\text { Standard } \\
\text { Error }\end{array}$ & $p$-Value & Coefficient & $\begin{array}{c}\text { Standard } \\
\text { Error }\end{array}$ & $p$-Value \\
\hline Longer forecasting horizon (Q13) & $-0.278^{* * *}$ & 0.065 & 0.000 & & & & $-0.291^{* * *}$ & 0.073 & 0.000 \\
\hline Increasing level of reliance on Beta $(\mathrm{Q} 14 \mathrm{c})$ & 0.002 & 0.104 & 0.986 & & & & -0.020 & 0.110 & 0.855 \\
\hline Increasing level of reliance on business risk (Q14e) & $0.469^{* * *}$ & 0.101 & 0.000 & & & & $0.438^{* * *}$ & 0.107 & 0.000 \\
\hline Increasing level of reliance on views of fund's participants/client (Q14h) & -0.006 & 0.095 & 0.950 & & & & -0.038 & 0.102 & 0.710 \\
\hline Increasing level of reliance on behavior of other market players (Q14i) & -0.058 & 0.088 & 0.511 & & & & 0.019 & 0.101 & 0.849 \\
\hline Rising level of risk aversion (Q15) & $0.210 * *$ & 0.090 & 0.021 & & & & $0.219 * *$ & 0.093 & 0.020 \\
\hline Rising level of loss aversion (Q16) & $0.163 *$ & 0.085 & 0.058 & & & & 0.096 & 0.092 & 0.297 \\
\hline Increasing importance of salary change as motivator (Q20a) & 0.150 & 0.092 & 0.105 & & & & $0.178^{*}$ & 0.095 & 0.065 \\
\hline $\begin{array}{l}\text { Increasing importance of senior management approval/disapproval as } \\
\text { motivator }(\mathrm{Q} 20 \mathrm{~d})\end{array}$ & 0.172 & 0.104 & 0.102 & & & & $0.206^{*}$ & 0.109 & 0.062 \\
\hline Increasing importance of client's approval/disapproval as motivator (Q20e) & 0.038 & 0.099 & 0.706 & & & & 0.028 & 0.113 & 0.805 \\
\hline Increasing importance of personal reputation as motivator $(\mathrm{Q} 20 \mathrm{f})$ & -0.110 & 0.115 & 0.339 & & & & -0.085 & 0.129 & 0.512 \\
\hline Rising age $(\mathrm{Q} 3)$ & & & & $-0.196^{* *}$ & 0.098 & 0.047 & -0.050 & 0.081 & 0.538 \\
\hline Rising educational level $(\mathrm{Q} 4)$ & & & & 0.125 & 0.107 & 0.246 & 0.049 & 0.089 & 0.585 \\
\hline Longer professional experience in current fund (Q6) & & & & $0.178^{*}$ & 0.091 & 0.053 & $0.138^{*}$ & 0.072 & 0.059 \\
\hline Type of fund managed rising with funds other than mutual (Q9) & & & & -0.396 & 0.270 & 0.145 & -0.121 & 0.227 & 0.594 \\
\hline Major investment segment rising with diminishing risk (Q10) & & & & $0.218^{*}$ & 0.125 & 0.085 & 0.039 & 0.103 & 0.703 \\
\hline Rising importance of relative fund performance in remuneration $(\mathrm{Q} 19 \mathrm{~b})$ & & & & 0.217 * & 0.121 & 0.075 & 0.025 & 0.110 & 0.822 \\
\hline Rising importance of assessment by superiors in remuneration $(\mathrm{Q} 19 \mathrm{c})$ & & & & 0.108 & 0.133 & 0.421 & $0.187^{*}$ & 0.112 & 0.097 \\
\hline Country dummies & & Yes & & & Yes & & & Yes & \\
\hline R-squared & & 0.582 & & & 0.240 & & & 0.613 & \\
\hline Adjusted R-squared & & 0.531 & & & 0.174 & & & 0.539 & \\
\hline ANOVA $\mathrm{F}$ & & $11.581^{* * *}$ & & & $3.617 * * *$ & & & $7.297^{* * *}$ & \\
\hline
\end{tabular}

* Significance at $10 \%$ level; ${ }^{* *}$ Significance at $5 \%$ level; ${ }^{* * *}$ Significance at $1 \%$ level. 
The results of Model (3), which contains both the "subjective" and "objective" factors simultaneously, are shown in the third column of Table 5. All statistically significant relationships identified in Model (1) in the group of "subjective" factors hold in the joint estimation (except for loss aversion), with the increasing importance of salary change and senior management approval/disapproval becoming statistically significant. The first of the above additional factors (importance of salary change) shows that fund managers increasingly perceive ESG issues as a tool that enables them to attain a higher appreciation of their job (and, thus, salary). The second factor (approval/disapproval of senior management) may shed some light on the existence of possible pressures from superiors to incorporate environmental, social and governance factors into individual portfolio management, which is further confirmed by statistical significance of the importance of assessment by senior management in the remuneration in Model (3) as an additional "objective" factor in the matrix of significance aside from longer work experience in the current fund. Although the age, investment segment characteristics and importance of relative fund performance in remuneration are not statistically significant anymore, the addition of more formalized features to the overall approach does provide some modest gains in the usefulness of the model.

Finally, in order to gain more in-depth understanding of the explanation capacity of our statistical procedure, we also used an ANOVA analysis. Additionally, we have also included country dummies in our models in order to control for possible country-specific effects.

\section{Discussion}

Our empirical evidence from a survey of bank-affiliated fund managers in five different countries shows that ESG issues gain importance in their short-term investment decision-making process and are strongly perceived as a protection from additional business risk. This is not surprising, since the magnitude of the possible market value loss due to corporate misconduct can be substantial and occur almost immediately after its discovery (e.g., the historic Torrey Canyon oil spill off the southwest coast of the United Kingdom in 1967; the Prestige oil spill which severely affected Spanish and Portugal coasts in 2002; the British Petroleum oil spill in Gulf of Mexico which happened in 2010; TEPCO cover-ups in the Fukushima disaster in 2011; and, more recently, the Volkswagen and Mitsubishi emissions scandals in 2015). Thus, it seems logical that the use of ESG is stronger among those fund managers, which are more concerned about the sort-term period. This finding is also in line with other studies suggesting ESG inclusion into an investment decision making process as a factor mitigating risk $[29,30]$. However, the finding on risk mitigation is in contrast with the traditional (and rather prevalent) approach in the literature connecting the implementation of ESG issues with a short-term negative impact on the company's financial performance, and, thus, suggesting that it is more reasonable to consider environmental, social and governance factors only from a longer-term investment perspective [85]. We also share the opinion that the usage of ESG criteria is profitable over the long run, however fund managers surveyed in our study generally perceive ESG screening as a protection against short-term risk. Thus, it can be interpreted as a behavioral act [86].

Our research also revealed that a more careful approach to ESG factors in portfolio management is positively affected by longer professional experience in the current fund. As herding behavior is more probable among investors from the same community [55,56], having similar investment experience, access to similar information or a common regulatory framework and environment within which they work [61], a stronger predisposition to incorporate ESG issues in investment decision making may thus occur as a result of longer work routine in a homogenous environment. Furthermore, the above predisposition is also more characteristic for asset managers who are more sensitive to herding through a higher dependency on relative fund performance in the overall remuneration. Finally, the higher importance ascribed to ESG issues among financial professionals is strongly and positively influenced by the increasing prominence of senior management approval/disapproval. This increased importance attributed to ESG issues is strictly connected with the necessity of incorporating a much wider spectrum of opinions into decision-making and follow the lead. It may also allow financial professionals to 
better explain their investment positions to superiors. Furthermore, positive relation between the predisposition to incorporate ESG issues into investment decision making and rising level of risk aversion presents the former as a tool to create more "peaceful" working environment in fund industry.

Surprisingly, our results indicated that a predisposition to incorporate ESG issues into investment decision making among asset managers is not significantly influenced by factors stated in the existing literature, such as the fashion/behavior of other market participants, views of the fund's participants/clients or reputational concerns $[3,5,48,87]$. This result may be explained by the relatively early stages of maturity of assets management companies in their marketing efforts, which generally fail to gain customer insight on the ESG issues and deliver the right product at the right time [88]. Finally, our results also suggest that ESG issues are not explicitly perceived by fund managers as a tool for additional long-term value creation. The insignificant role in our empirical models seen for the level of reliance on fundamental analysis as potential predictor of general predisposition to incorporate environmental, social and governance factors into the investment decision making process among finance professionals serves as a justification for the argument of low importance of long-term value creation. In addition, the possible low importance of ESG criteria in the long-term investment strategy may be also explained by the immature environmental, social and governance investment infrastructure, which is just being built in digital platforms [88].

\section{Conclusions}

A better understanding of the factors shaping mutual fund managers' predisposition to incorporate ESG issues in investment decision making is of particular importance. This paper presents empirical evidence from a survey of bank-affiliated mutual fund managers in five different countries to address the following questions: (1) Is the predisposition to incorporate ESG issues in investment decision making influenced more by "objective" (e.g., professional experience, type of fund managed, and major investment segment) or "subjective" (e.g., personal points of view, attitudes, and perceptions) manager characteristics? (2) Is the strength of the above tendency motivated more by risk aversion, a tendency to herd or a desire to create additional value?

We can summarize our results as follows: a general predisposition to incorporate environmental, social and governance factors into the investment decision making process among asset managers is much strongly motivated by "subjective" behavioral factors (with "objective" factors playing only supportive role); the strength of above tendency is generally shaped by the willingness to mitigate risk (especially in a short-term horizon) and the tendency to herd, and is not explicitly connected with additional value creation potential.

Our study can be placed in the area of behavioral finance, where fund managers are more preoccupied with ESG issues because of their personal perceptions and/or real personal situations than of their explicit goal of value creation. On the other hand, financial professionals are acting as if ESG screening was more important over the short-term. The above short-termism is in contrast with traditional long-term approach and is again in line with behavioral finance models.

As a corollary of our research it is worth to highlight the clear difference in the length of forecasting horizon between continental European and Anglo-Saxon fund managers. The above finding confirms the general cultural pattern stated in the existing body of literature [79].

This study contributes not only to the academic discussion on the fund manager's motivations toward ESG issues but also sheds light on the true reasons for ESG investment strategy implementation in the fund management industry. These reasons seem to be more related to risk aversion and herding behavior than the creation of additional value.

We have increased the awareness of factors that play a crucial role in enhancing the level of importance ascribed to ESG factors among asset managers and the factors that specifically encourage/discourage such a tendency. These factors are more "subjective" in nature, like investment horizon or attitude toward risk, rather than "objective", such as age, education or number of years of professional experience. 
The obtained results have implications for initiatives such as Principles for Responsible Investment (PRI), which should help them better position its goals among the investors community, by putting stronger emphasis on short-term risk mitigation and thus enhancing the effectiveness of their implementation among financial professionals. They may also be useful for the asset management industry in general in supporting its activities to better incorporate environmental, social and governance factors into portfolio management.

The method employed in this study has several limitations. First, our sample was restricted to bank-affiliated asset management firms, which can make obtained results less generalizable and specific to the analyzed sample. Thus, future research should also focus on other funds and market players. Second, due to some fundamental differences in the selected fund managers' characteristics among the analyzed countries (especially Spain), an interesting area for future research is to explore the nature and causes of the predisposition to incorporate ESG issues into investment decision making for single markets and cultural environments (with a substantially higher number of context-specific questionnaires). Finally, the results may be affected by the particular time period within which the questionnaires were collected (the aftermath of the global financial crisis). It stands as an important challenge for future research.

Acknowledgments: The authors would like to thank all the fund managers that participated in the survey for their time and effort in answering our questionnaire. Financial support of the DEIKER and Deusto Business School is greatly appreciated.

Author Contributions: All authors contributed to each section of the article equally.

Conflicts of Interest: The authors declare no conflict of interest.

\section{Appendix A}

The Questionnaire (Only questions used in this study are provided here. Complete list of 24 questions available upon request.)

Q1: When you make an investment decision, ESG issues are of: (No importance, Low importance, Moderate importance, Average importance, Considerable importance, Extreme importance):

Q2: Gender (Male, Female)

Q3: Age (<30, 30-34, 35-39, 40-44, 45-49, >49)

Q4: Educational level (Non academic, Bachelor Grade from national University, Bachelor Grade from foreign University, Master Grade from national University, Master Grade from foreign University, Ph.D. degree)

Q5: Professional experience in asset management in general (in years) $(<3,3-5,6-8,9-11,12-14,>14)$

Q6: Professional experience in current fund (in years) $(<3,3-5,6-8,9-11,12-14,>14)$

Q7: Average working hours per week $(<36,36-40,41-45,46-50,51-55,>55)$

Q8 (modified on the basis of Gehrig et al. [81]): Average number of hours per week for data procurement and research activities $(<5,5-10,11-15,16-20,21-25,>25)$

Q9: Type of fund managed (Mutual fund, Pension fund, Life insurance fund, Private client fund, Other) Q10: Major investment segment (Equities, Bonds, Money Market, Derivatives, Other funds)

Q11: Your company total assets under management (thousands of millions of EUR) $(<1,1-5,5-10$, 10-15, 15-20, >20)

Q12: Assets under your personal management (millions of EUR) $(<50,50-100,100-250,250-500$, 500-1000, >1000)

Q13: When you make an investment decision, your average forecasting horizon is (Intraday, 1-7 days, 8-30 days, 2-6 months, 6-12 months, More than 12 months)

Q14: When you make an investment decision, you base your choice on (please classify each option) (No importance, Low importance, Moderate importance, Average importance, Considerable importance, Extreme importance): 
Q14a: Fundamental analysis

Q14b: Technical analysis

Q14c: Beta as a measure of risk

Q14d: Volatility of return

Q14e: Business risk

Q14f: Discussion with colleagues

Q14g: Views of fund's senior management

Q14h: Views of fund's participants/clients

Q14i: Behavior of other market players

Q14j: Statements of industry leaders

Q14k: Statements of economic leaders

Q141: Statements of government leaders

Q15: Please, classify your attitude toward risk in your professional investment decisions (Not risk averse, Little risk averse, Moderate risk averse, Average risk averse, Considerable risk averse, Extreme risk averse)

Q16: (adopted directly from Lütje [82]): To what extent do you agree with the following statement (Not at all, Slightly, Moderately, Averagely, Considerably, Extremely)

In case of loss positions in portfolio you prefer to wait for price to rebound itself instead of selling those positions.

Q17: (adopted directly from Menkhoff [83]): In your opinion, the market usually fully incorporates fundamental information into stock prices within (Intraday, 1-7 days, 8-30 days, 2-6 months, 6-12 months, More than 12 months)

Q18: (adopted directly from Menkhoff [83]): How long, in your opinion, can you afford to hold a loss-making position (Intraday, 1-7 days, 8-30 days, 2-6 months, 6-12 months, More than 12 months) Q19: Which criteria are decisive for the amount of your performance-based remuneration (please classify each option) (No importance, Low importance, Moderate importance, Average importance, Considerable importance, Extreme importance):

Q19a: Absolute fund performance

Q19b: Relative fund performance

Q19c: Assessment by superiors

Q19d: Assessment by colleagues

Q19e: Business development of the asset management company

Q20: (modified on the basis of Baker [84]): What is the importance of following factors as motivators to achieve superior investment performance/avoid bad performance (please classify each option) (No importance, Low importance, Moderate importance, Average importance, Considerable importance, Extreme importance):

Q20a: Salary change

Q20b: Position change (promotion/demotion)

Q20c: Loss of job

Q20d: Senior management approval/disapproval

Q20e: Client's approval/disapproval

Q20f: Personal reputation 


\section{References}

1. European Social Investment Forum (EUROSIF). European SRI Study 2014. Available online: http://www. eurosif.org/wp-content/uploads/2014/09/Eurosif-SRI-Study-20142.pdf (accessed on 23 May 2016).

2. Staub-Bisnang, M. Sustainable Investing for Institutional Investors-Risks, Regulations and Strategies; John Wiley \& Sons: Singapore, 2012.

3. US Social Investment Forum (USSIF). Report on US Sustainable, Responsible and Impact Investing Trends 2014. Available online: http://www.ussif.org/Files/Publications/SIF_Trends_14.F.ES.pdf (accessed on 23 May 2016).

4. Global Sustainable Investment Review (GSIR). Global Sustainable Investment Review 2014. Available online: http://www.gsi-alliance.org/wp-content/uploads/2015/02/GSIA_Review_download.pdf (accessed on 23 May 2016).

5. Brown, N.; Deegan, C. The Public Disclosure of Environmental Performance Information-A Dual Test of Media Agenda Setting Theory and Legitimacy Theory. Account. Bus. Res. 1998, 29, 21-41. [CrossRef]

6. Kiernan, M.J. Universal owners and ESG: Leaving money on the table? Corp. Gov. Int. Rev. 2007, 15, 478-485. [CrossRef]

7. Yegnasubramanian, A. Environmental, Social and Governance: Moving to Mainstream Investing? Available online: http:/ /www.bsr.org/reports/BSR_ESG_Mainstream_Investing.pdf (accessed on 23 May 2016).

8. Boerner, H. Sustainability and ESG reporting frameworks: Issuers have GAAP and IFRS for reporting financials-What about reporting for intangibles and non-financials? Corp. Financ. Rev. 2011, 15, 34-37.

9. Diltz, D.J. Does Social Screening Affect Portfolio Performance? J. Investig. 1995, 4, 64-69. [CrossRef]

10. Sahut, J.M.; Pasquini-Descomps, H. ESG Impact on Market Performance of Firms: International Evidence. Int. Manag. 2015, 19, 40-63. [CrossRef]

11. DeZwaan, L.; Brimble, M.; Stewart, J. Member perceptions of ESG investing through superannuation. Sustain. Account. Manag. Pol. J. 2015, 6, 79-102. [CrossRef]

12. Fernandez, R.; Elfner, N. ESG Integration in Corporate Fixed Income. J. Appl. Corp. Financ. 2015, $27,64-72$. [CrossRef]

13. Auer, B.R.; Schuhmacher, F. Do socially (ir)responsible investments pay? New evidence from international ESG data. Q. Rev. Econ. Financ. 2016, 59, 51-62. [CrossRef]

14. Czerwińska, T.; Kaźmierkiewicz, P. ESG Rating in Investment Risk Analysis of Companies Listed on the Public Market in Poland. Econ. Notes 2015, 44, 211-248. [CrossRef]

15. Halbritter, G.; Dorfleitner, G. The wages of social responsibility-Where are they? A critical review of ESG investing. Rev. Financ. Econ. 2015, 26, 25-35. [CrossRef]

16. Mitsuyama, N.; Shimizutani, S. Stock market reaction to ESG-oriented management: An event study analysis on a disclosing policy in Japan. Econ. Bull. 2015, 35, 1098-1108.

17. Barber, J. Mapping the movement to achieve sustainable production and consumption in North America. J. Clean. Prod. 2007, 15, 499-512. [CrossRef]

18. Derwall, J.; Koedijk, K.; Ter Horst, J. A tale of values-driven and profit-seeking social investors. J. Bank. Financ. 2011, 35, 2137-2147. [CrossRef]

19. Borgers, A.; Derwall, J.; Koedijk, K.; Horst, J. Do social factors influence investment behavior and performance? Evidence from mutual fund holdings. J. Bank. Financ. 2015, 60, 112-126. [CrossRef]

20. Hong, H.; Kostovetsky, L. Red and blue investing: Values and finance. J. Financ. Econ. 2012, 103, 1-19. [CrossRef]

21. McLachlan, J.; Gardner, J. A Comparison of Socially Responsible and Conventional Investors. J. Bus. Ethics 2004, 52, 11-25. [CrossRef]

22. Bauer, R.; Smeets, P. Social identification and investment decisions. J. Econ. Behav. Organ. 2015, 117, $121-134$. [CrossRef]

23. Nilsson, J. Segmenting socially responsible investors: The influence of financial return and social responsibility. Int. J. Bank Mark. 2009, 27, 5-31. [CrossRef]

24. Glac, K. Understanding Socially Responsible Investing: The Effect of Decision Frames and Trade-off Options. J. Bus. Ethics 2009, 87, 41-55. [CrossRef]

25. Van Duuren, E.; Plantinga, A.; Scholtens, B. Esg integration and the investment management process: Fundamental investing reinvented. J. Bus. Ethics 2016, in press. [CrossRef] 
26. Bollen, N.P.B. Mutual Fund Attributes and Investor Behavior. J. Financ. Quant. Anal. 2007, 42, 683-708. [CrossRef]

27. Fama, E.F. Efficient Capital Markets: A Review of Theory and Empirical Work. J. Financ. 1970, $25,373-417$. [CrossRef]

28. Fama, E.F. Efficient Capital Markets: II. J. Financ. 1991, 46, 1575-1617. [CrossRef]

29. Derwall, J.; Guenster, N.; Bauer, R.; Koedijk, K. The Eco-Efficiency Premium Puzzle. Financ. Anal. J. 2005, 61, 51-63. [CrossRef]

30. Bertrand, P.; Lapointe, V. How Performance of Risk-Based Strategies Is Modified by Socially Responsible Investment Universe? Int. Rev. Financ. Anal. 2015, 38, 175-190. [CrossRef]

31. Arnott, R.; Hsu, J.; Moore, P. Fundamental Indexation. Financ. Anal. J. 2005, 61, 83-99. [CrossRef]

32. Weber, E.U.; Blais, A.R.; Betz, N.E. A domain-specific risk-attitude scale: Measuring risk perceptions and risk behaviors. J. Behav. Decis. Mak. 2002, 15, 263-290. [CrossRef]

33. Chen, L.H.; Baker, S.P.; Braver, E.R.; Li, G. Carrying passengers as a risk factor for crashes fatal to 16- and 17-year-old drivers. J. Am. Med. Assoc. 2000, 283, 1578-1582. [CrossRef]

34. Finer, L.B. Unintended pregnancy among U.S. adolescents: Accounting for sexual activity. J. Adolesc. Health 2010, 47, 312-314. [CrossRef] [PubMed]

35. Shulman, E.P.; Cauffman, E. Deciding in the dark: Age differences in intuitive risk judgment. Dev. Psychol. 2014, 50, 167-177. [CrossRef] [PubMed]

36. Wiernik, B.M.; Ones, D.S.; Dilchert, S. Age and environmental sustainability: A meta-analysis. J. Manag. Psychol. 2013, 28, 826-856. [CrossRef]

37. Huang, H.C.; Lin, T.H.; Lai, M.C.; Lin, T.L. Environmental consciousness and green customer behavior: An examination of motivation crowding effect. Int. J. Hosp. Manag. 2014, 40, 139-149. [CrossRef]

38. Byrnes, J.P.; Miller, D.C.; Schafer, W.D. Gender differences in risk taking: A meta-analysis. Psychol. Bull. 1999, 125, 367-383. [CrossRef]

39. Watson, J.; McNaughton, M. Gender differences in risk aversion and expected retirement benefits. Financ. Anal. J. 2007, 63, 52-62. [CrossRef]

40. Dwyer, P.D.; Gilkeson, J.H.; List, J.A. Gender differences in revealed risk taking: Evidence from mutual fund investors. Econ. Lett. 2002, 76, 151-158. [CrossRef]

41. Croson, R.; Gneezy, U. Gender differences in preferences. J. Econ. Lit. 2009, 47, 448-474. [CrossRef]

42. Olsen, R.A.; Cox, C.M. The influence of gender on the perception and response to investment risk: The case of professional investors. J. Psychol. Financ. Markets 2001, 2, 29-36. [CrossRef]

43. De Silva, D.G.; Pownall, R.A.J. Going green: Does it depend on education, gender or income? Appl. Econ. 2014, 46, 573-586. [CrossRef]

44. Shupp, R.S.; Williams, A.W. Risk preference differentials of small groups and individuals. Econ. J. 2008, 118, 258-283. [CrossRef]

45. Baker, R.J.; Laury, S.K.; Williams, A.W. Comparing small-group and individual behavior in lottery-choice experiments. South. Econ. J. 2008, 75, 367-382. [CrossRef]

46. Adams, R.; Ferreira, D. Moderation in groups: Evidence from betting on ice break-ups in Alaska. Rev. Econ. Stud. 2010, 77, 882-913. [CrossRef]

47. Rockenbach, B.; Sadrieh, A.; Mathauschek, B. Teams take the better risks. J. Econ. Behav. Organ. 2007, 63, 412-422. [CrossRef]

48. Fineman, S.; Clarke, K. Green Stakeholders: Industry interpretations and response. J. Manag. Stud. 1996, 33, 715-730. [CrossRef]

49. Llewellyn, J. The Business of Climate Change: Challenges and Opportunities. Available online: http://www.lehmantrust.biz/who/intellectual_capital/pdf/business_of_climate_change_i.pdf (accessed on 23 May 2016).

50. Chang, C.H.; Lin, S.J. The effects of national culture and behavioral pitfalls on investors' decision-making: Herding behavior in international stock markets. Int. Rev. Econ. Financ. 2015, 37, 380-392. [CrossRef]

51. Scharfstein, D.S.; Stein, J.C. Herd behavior and investment. Am. Econ. Rev. 1990, 80, 465-479.

52. Clement, M.; Tse, S.Y. Financial analyst characteristics and herding behaviour in forecasting. J. Financ. 2005, 60, 307-341. [CrossRef]

53. Dass, N.; Massa, M.; Patgiri, R. Mutual funds and bubbles: The surprising role of contractual incentives. Rev. Financ. Stud. 2008, 21, 51-99. [CrossRef] 
54. Yang, W.R. Herding with costly information and signal extraction. Int. Rev. Econ. Financ. 2011, $20,624-632$. [CrossRef]

55. Demarzo, P.M.; Kaniel, R.; Kremer, I. Diversification as a public good: Community effects in portfolio choice. J. Financ. 2004, 59, 1677-1716. [CrossRef]

56. Brown, J.R.; Ivkovic, Z.; Smith, P.A.; Weisbenner, S. Neighbors matter: Casual community effects and stock market participation. J. Financ. 2008, 63, 1509-1531. [CrossRef]

57. Nofsinger, J.R.; Sias, R.W. Herding and feedback trading by institutional and individual investors. J. Financ. 1999, 54, 2263-2295. [CrossRef]

58. Venezia, I.; Nashikkar, A.; Shapira, Z. Firm specific and macro herding by professional and amateur investors and their effects on market volatility. J. Bank. Financ. 2011, 35, 1599-1609. [CrossRef]

59. Ioannou, I.; Serafeim, G. The impact of corporate social responsibility on investment recommendations: Analysts' perceptions and shifting institutional logics. Strateg. Manag. J. 2015, 36, 1053-1081. [CrossRef]

60. Teh, L.; De Bondt, W. Herding behavior and stock returns: An exploratory investigation. Swiss J. Econ. Stat. 1997, 133, 293-324.

61. Voronkova, S.; Bohl, M.T. Institutional traders' behaviour in an emerging stock market: Empirical evidence on Polish pension fund investors. J. Bus. Financ. Account. 2005, 32, 1537-1560. [CrossRef]

62. Bennett, J.R.; Sias, R.; Starks, L. Greener pastures and the impact of dynamic institutional preferences. Rev. Financ. Stud. 2003, 16, 1203-1238. [CrossRef]

63. Semmann, D.; Krambeck, H.; Milinski, M. Reputation is valuable within and outside one's social group. Behav. Ecol. Sociobiol. 2005, 57, 611-616. [CrossRef]

64. Wedekind, C.; Braithwaite, V. The long-term benefits of human generosity in indirect reciprocity. Curr. Biol. 2002, 12, 1012-1015. [CrossRef]

65. Barclay, P. Trustworthiness and competitive altruism can also solve the "tragedy of the commons". Evol. Hum. Behav. 2004, 25, 209-220. [CrossRef]

66. Stiff, C.E.; Van Vugt, M. The power of reputations: The role of third party information in the admission of new group members. Group Dyn. 2008, 12, 155-166. [CrossRef]

67. Henrich, J.; Gil-White, F.J. The evolution of prestige: Freely conferred deference as a mechanism for enhancing the benefits of cultural transmission. Evol. Hum. Behav. 2001, 22, 165-196. [CrossRef]

68. Ozaki, R. Adopting sustainable innovation: What makes consumers sign up to green electricity? Bus. Strategy Environ. 2011, 20, 1-17. [CrossRef]

69. Margolis, J.; Walsh, J. Misery Loves Companies: Rethinking Social Initiatives by Business. Admin. Sci. Q. 2003, 48, 268-305. [CrossRef]

70. Tyagi, R.; Sharma, A.K. Corporate Social Performance and Corporate Financial Performance: A Link for the Indian Firms. Issues Soc. Environ. Account. 2013, 7, 4-29.

71. Porter, E.M.; Kramer, R.K. Creating Shared Value. Harv. Bus. Rev. 2011, 1-2, 62-77.

72. Turban, D.; Greening, D.W. Corporate social performance and organizational attractiveness to prospective employees. Acad. Manag. Rev. 1996, 40, 658-672. [CrossRef]

73. Chernev, A.; Blair, S. Doing Well by Doing Good: The Benevolent Halo of Corporate Social Responsibility. J. Consum. Res. 2015, 41, 1412-1425. [CrossRef]

74. Chapple, W.; Harris, R.; Paul, C.J.M. The cost implications of waste reduction: Factor demand, competitiveness and policy implications. J. Prod. Anal. 2006, 26, 245-258. [CrossRef]

75. Barnett, M.L. Shareholder influence capacity and the variability of finance returns to corporate social responsibility. Acad. Manag. Rev. 2007, 22, 794-816. [CrossRef]

76. Przychodzen, J.; Przychodzen, W. Corporate Sustainability and Shareholder Wealth. J. Environ. Plan. Manag. 2013, 56, 474-493. [CrossRef]

77. Cordeiro, J.; Tewari, M. Firm Characteristics, Industry Context, and Investor Reactions to Environmental CSR: A Stakeholder Theory Approach. J. Bus. Ethics 2015, 130, 833-849. [CrossRef]

78. Bassen, A.; Kovács, A. Environmental, Social and Governance Key Performance Indicators from a Capital Market Perspective. Z. Wirtsch.- Unternehmensethik 2008, 9, 182-192.

79. Sinclair, T.J. Passing judgement: Credit rating processes as regulatory mechanisms of governance in the emerging world order. Rev. Int. Polit. Econ. 1994, 1, 133-159. [CrossRef]

80. Moore, R. Managing Troubles in Answering Survey Questions: Respondents' Uses of Projective Reporting. Soc. Psychol. Quart. 2004, 67, 50-69. [CrossRef] 
81. Gehrig, T.P.; Lütje, T.; Menkhoff, L. Bonus Payments and Fund Managers' Behavior: Transatlantic Evidence. CESifo Econ. Stud. 2009, 55, 569-594. [CrossRef]

82. Lütje, T. To be good or to be better: Asset manager's attitudes towards herding. Appl. Financ. Econ. 2009, 19, 825-839. [CrossRef]

83. Menkhoff, L. Short-term horizons in foreign exchange? Survey evidence from dealers and fund managers. KYKLOS 2001, 54, 27-48. [CrossRef]

84. Baker, M. Fund managers' attitudes to risk and time horizons: The effect of performance benchmarking. Eur. J. Financ. 1998, 4, 257-278. [CrossRef]

85. Peloza, J. The Challenge of Measuring Financial Impacts from Investments in Corporate Social Performance. J. Manag. 2009, 35, 1518-1541. [CrossRef]

86. Gómez-Bezares, F.; Przychodzen, W.; Przychodzen, J. Corporate Sustainability and Shareholder Wealth-Evidence from British Companies and Lessons from the Crisis. Sustainability 2016, 8, 276. [CrossRef]

87. Alkemade, F.; Castaldi, C. Strategies for the Diffusion of Innovations on Social Networks. Comput. Econ. 2005, 25, 3-23. [CrossRef]

88. Coen, A. Fund Managers Increasing ESG Focus. Money Manag. Executive 2014, 22, 1-6.

(C) 2016 by the authors; licensee MDPI, Basel, Switzerland. This article is an open access article distributed under the terms and conditions of the Creative Commons Attribution (CC-BY) license (http://creativecommons.org/licenses/by/4.0/). 